\title{
The Preparation of Accelerator Targets by the Evaporation of Acetate-Organic Solutions in the Presence of $\mathrm{NH}_{3}$ Gas
}

\author{
Shan-Yu Cai*, A. Ghiorso, Darleane C. Hoffman
}

*On leave from the Radioisotope Division, Institute of Atomic Energy, P. 0. Box $275(66)$, Beijing, China

Nuclear Science Division, Lawrence Berkeley Laboratory, University of Cal ifornia, Berkeley, California 94720

LBL $-\mathbf{- 2 3 4 0}$

DE87 013985

\section{DISCLAIMER} \begin{abstract}
This report was prepared as an account of work sponsored by an agency of the United States employees, makes any warranty, express or implied, or assumes ancy thereof, nor any of their bility for the accuracy, completeness, or usefulness, or assumes any legal liability or responsiprocess disclosed, or represents that its use would of any information, apparatus, product, or ence herein to any specific commercial product, process, or serice privately owned rights. Refermanufacturer, or otherwise does not necessarily cocess, or service by trade name, trademark, mendation, or favoring by the United States Govertitute or imply its endorsement, recom. and opinions of authors expressed herein do not necess or any agency thereof. The views United States Government or any agency theref not necessarily state or reflect those of the
\end{abstract}

This work was supported by the Director, Office of Energy Research, Division of Nuclear Physics of the Office of High Energy and Nuclear Physics of the U.S. Department of Energy under Contract No. DE-AC03-76SF00098. 
The Preparation of Accelerator Targets by the Evaporation of Acetate-Organic Solutions in the Presence of $\mathrm{NH}_{3}$ Gas

Shan-Yu Cai*, A. Ghiorso, Darleane C. Hoffman

*On leave from the Radioisotope Division, Institute of Atomic Energy, P. O. Box 275(66), Beijing, China

Nuclear Science Division, Lawrence Berkeley Laboratory, University of California, Berkeley, California 94720

The chemical methods described in this paper have been developed for preparation of isotopic targets for bombardment by accelerator-produced ions. Three systems are compared: nitrate-, chloride-, and acetate-organic solutions. The best method was found to be the metallic acetate-organic solution system, evaporated onto the substrate in the presence of ammonia gas. A detailed procedure is given for this method.

The targets obtained by the acetate-organic solution system are uniform and adherent. The hydroxide forms fine crystals of good quality for target thicknesses from a few $\mu \mathrm{g} / \mathrm{cm}^{2}$ to several $\mathrm{mg} / \mathrm{cm}^{2}$. Thicknesses up to $5 \mathrm{mg} / \mathrm{cm}^{2}$ of Eu as the oxide were obtained by this method. The process is simple and fast.

\section{Introduction}

Many techniques have been employed to make targets for accelerator bombardments. Among them are evaporation, 1,2 vacuum sublimation, 3,4 electrospraying, ${ }^{5,6,7}$ ion implantation, ${ }^{8}$ powder pressing, 9 ana electrodeposition or molecular plating, ${ }^{10-18}$ etc. Each has its own merits and drawbacks.

For vacuum sublimation (using resistance or electron bombardnent heating), electrospraying or ion implantation techniques, the drawbacks are either the complexity of equipment or the difficulty of the procedure. With regard to powder pressing, a number of materials are needed to make the targets. 
Molecular plating has long been used for the preparation of targets ana radioactive sources. The deposits are in most cases uniform and adherent. However, each layer cannot be more than $100 \mu \mathrm{g} / \mathrm{cm}^{2}$ thick. In order to obtain thicker layers, the deposit on the backing material is calcined in a muffle furnace, and then the plating procedure is repeated. However, the overall time for this procedure for preparing thicker targets is very long. In addition, the deposits can be partially dissolved while the electrolyte solution is added to or removed from the cell and this can affect the quality of the target. In general, target thicknesses up to about $1 \mathrm{mg} / \mathrm{cm}^{2}$ can be obtained. The yield of deposition is usually from 70 to $90 \%$.

The method of evaporating a solution is very simple, but the trouble is that each drop which is evaporated can be dissolved by the addition of the next. For this reason, it is difficuit to get uniform and adherent targets.

One way to solve this main problem is to change the chemical form after each drop is deposited. For example, it is possible to continuously convert the metallic salt into the hydroxide. This hydroxide can subsequently be converted to the oxide which is insoluble. The following sections are devoted to a detailed description of the experiments that were undertaken to determine the optimum chemical conditions for taking advantage of this idea.

\section{Experimental}

2.1 Preparation of the feed solutions

Most of the experiments were done with lanthanum and europium compounds; however, samples prepared with samarium, neodymium and praseodymium were of equal quality. 
Lanthanum nitrate, $\mathrm{La}\left(\mathrm{NO}_{3} \cdot 6 \mathrm{H}_{2} \mathrm{O}\right.$, was dissolved in dilute nitric acid. Europium oxide (purity 99\%) was dissolved in dilute hydrochloric or acetic acid. In order to increase the solubility of $\mathrm{Eu}_{2} \mathrm{O}_{3}$ in acetic acid, heating was necessary.

The above acidic solutions were pipetted into centrifuge tubes and dried. The dry material was then dissolved in a mixture of water and ethanol. The resulting solutions were dried again.

Finally, the dry material was dissolved in the different mixtures of organic solutions, forming stock solutions with concentrations of less than $0.2 \mathrm{mg} / \mathrm{ml}$.

\subsection{Backing material}

The following thin metal foils were used as backing materials, aluminum ( $5 \times$ $10^{-2} \mathrm{~mm}$ thick), beryllium $\left(1.3 \times 10^{-2} \mathrm{~mm}\right.$ thick $)$, platinum $\left(2 \times 10^{-3} \mathrm{~mm}\right.$ thick $)$.

Prior to preparing the target, it was necessary to clean the backing material. Each foil was washed with $\mathrm{HNO}_{3}, \mathrm{H}_{2} \mathrm{O}$, or acetone depending on which foil was used, by means of an ultrasonic cleaner. Subsequently, the foils were rinsed with alcohol or acetone and dried. The quality of the layers was excellent on the above substrates because the organic solution does not attack $A], B e$, or $\mathrm{Pt}$ roils.

\subsection{Ammonia gas}

Concentrated ammonium hydroxide was poured into a plastic wash-bottle which could be squeezed to produce hydrous $\mathrm{NH}_{3}$ gas. An ammonia cylinder (anhydrous) was also used in the experiments, but it was found that for good targets the ammionia should be hydrated. 
2.4 Other equipment

A hot plate was used for heating the substrate. The temperature of the substrate could be controlled automatically, and was measurea by an ion-constanten thermocouple. A muffle furnace was used to convert the hydroxide to the oxide at $450-550^{\circ}$. The quality of targets was observed by means of a microscope $(x 5)$.

\subsection{Defining the area of each target}

In order to define the area of a target, a circular paper disk ( 6 or $8 \mathrm{~mm})$ was wet with water and stuck to the Al or Be foil. Orr-Lac (spray lacquer) was sprayed onto the substrate. After the lacquer had dried, the paper was removed from the substrate and the circular area was cleaned with ethanol. The advantage of lacquer is that it cannot be decomposed at $130^{\circ} \mathrm{C}$, but it can be carbonized at $450-550^{\circ} \mathrm{C}$.

\subsection{The method of preparing targets}

The substrate is heated at constant temperature by a hot plate. The organic solution containg the metallic salt is dropped onto the substrate in $20 \mu l$ or $25 \mu \mathrm{l}$ aliquots. In order to get a uniform and circular deposit, it is important to control the evaporation of the original drops (1-3 drops). Because of the low surface tension of the organic solution, the best way to do this is to keep the tip of the pipette in touch with the drop until it dries.

As the drops of solution are being evaporated, ammonia gas is continuously blown over the surface to convert the salt into its hydroxide form. After each drop is dried, the next drop can be pipetted onto the surface without dissolving the previous material. In this way, the process is repeated until the target reaches the desired thickness. The target is then placed in an oven at 
$450-550^{\circ} \mathrm{C}$ for 15 minutes to convert the hydroxide to the oxide form. This procedure works well for targets up to $500 \mu \mathrm{g} / \mathrm{cm}^{2}$, but for thicker targets, more than $0.5 \mathrm{mg} / \mathrm{cm}^{2}$, it is best to built them up in layers of $\sim 200 \mu \mathrm{g} / \mathrm{cm}^{2}$ each, with conversion to the oxide after each layer is completed.

\section{Results}

\subsection{Choosing the solvent.}

To prevent introduction of undesirable impurities, all reagents used should be of the highest possible purity.

Experiments indicate that using acidic solution as a solvent in preparing the targets is inadvisable, because each drop will dissolve the previously deposited drop, even after the deposit has been converted to the hydroxide form by $\mathrm{NH}_{3}$ gas.

Pure water also does not work well as a solvent, although it easily dissolves the acetate. The main problem with water as a solvent is that the surface tension of the solution is too high and the evaporation of the solution is too slow. Furthermore, the target material cracks easily because the ammonium salt which is formed in the reaction of ammonia and metallic salts dissolves in water.

It was found that an organic solvent system is more suitable than an aqueous solution. As a result of comparing several organic solvents, such as acetone, ethyl ether, ethanol, isopropanol (2-propanol), isobutyl alcohol, butyl alcohol, ethylene glycol, toluene, and TTA-MIBK, isopropanol was found to be superior to the others.

\subsection{Nitrate-organic solution system}

Rare earth or other metallic nitrates react with ammonia gas to form the hydroxides when the solution contains water or $\mathrm{OH}^{-}$. The chemical reaction is as follows:

$$
\begin{aligned}
& \mathrm{La}\left(\mathrm{NO}_{3}\right)_{3}+3 \mathrm{NH}_{3}+3 \mathrm{H}_{2} \mathrm{O} \longrightarrow \mathrm{La}(\mathrm{OH})_{3} \downarrow+3 \mathrm{NH}_{4} \mathrm{NO}_{3} \\
& \left.2 \mathrm{NH}_{4} \mathrm{NO}_{3} \frac{210^{\circ} \mathrm{C}}{\Delta} \rightarrow 2 \mathrm{NH}_{3} \uparrow+\mathrm{N}_{2} \mathrm{O}_{5} \uparrow+\mathrm{H}_{2} \mathrm{O}\right\}
\end{aligned}
$$


The influence of the water content in the nitrate-isopropanol system has been studied for water concentrations in isopropanol of $2 \%, 5 \%, 10 \%, 15 \%$ and $20 \%$. These experiments indicate that water causes nonuniform layers which tend to crack and peel off the substrate.

When using ethanol-isopropanol as a mixed solvent, it was found that several grooves were ususally observed and circular cracking still took place with solutions in which the amount of ethanol was $2 \%, 4 \%, 6 \%$ and $8 \%$, because a small quantity of water present in the ethanol can dissolve $\mathrm{NH}_{4} \mathrm{NO}_{3}$ which cannot be decomposed at lower temperatures.

Pure isopropano? also does not work well. Crystals of $\mathrm{NH}_{4} \mathrm{NO}_{3}$ are formed and the $\mathrm{NH}_{4} \mathrm{NO}_{3}$ layers become thicker and thicker. A lot of small holes were left in the target after calcining at $450-550^{\circ} \mathrm{C}$.

The temperature of the substrate can be increased to more than $210^{\circ} \mathrm{C}$ during the pipetting of the solution. However, there are problems with the drop of solution sputtering off the substrate when the temperature is higher than $180^{\circ} \mathrm{C}$. Furthermore, the higher the temperature, the less favorable is the chemical reaction for producing the rare earth hydroxide.

\subsection{Chloride-organic solution system}

Rare earth or other metallic chlorides can also react with ammonia gas to form hydroxides when the solution contains $\mathrm{H}_{2} \mathrm{O}$ or $\mathrm{OH}^{-}$. The chemical reaction is as follows:

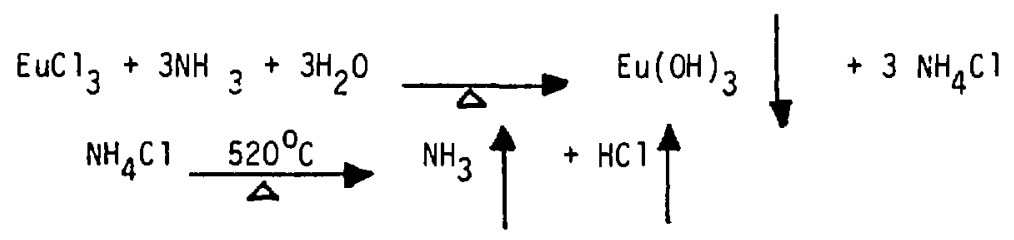


Based on the same consideration as for the others, the influence of water concentration in the $\mathrm{EuCl}_{3}$-isopropanol solution of $2 \%, 5 \%, 10 \%$ and $20 \%$ was investigated. Experiments showed that the main problem is a buildup of $\mathrm{NH}_{4} \mathrm{Cl}$ on the target because not all of it is removed by heating while the target is being deposited. Subsequent drops readily dissolve this $\mathrm{NH}_{4} \mathrm{Cl}$ and cause its redistribution on the target face. The edge of the target was found to be thicker than the center and a lot of small holes were left after the calcining operation.

The ethanol-isopropariol with chloride system has also been studied. Experiments were carried out with the amount of ethanol in isopropanol at $4 \%, 6 \%$, $8 \%$ and $10 \%$. These experiments indicate that the $\mathrm{NH}_{4} \mathrm{Cl}$ layer became thicker and thicker as the drops were added and the deposits partially dissolved in the next drop. Also, many small holes were produced after calcining.

In the case of pure isopropanol as a solvent for $\mathrm{EuCl}_{3}$, the next arop cannot dissolve the previously deposited drop. The crystals of hydroxide obtained in this case are much finer than those from the nitrate-isopropanol system. However, when the thickness of the targets is more than $500 \mu \mathrm{g} / \mathrm{cm}^{2}$, many tiny holes are formed after calcining at $550^{\circ}-600^{\circ} \mathrm{C}$ becasue of the decomposition of $\mathrm{NH}_{4} \mathrm{Cl}$. If the targets are calcined after each $200 \mu \mathrm{g} / \mathrm{cm}^{2}$ layer, and the process of evaporating and calcining is repeated, the uniformity and adherence can be improved.

\subsection{Acetate-organic solution system.}

Rare earth or other metallic acetates are similar to the nitrate and chloride systems and make use of the following reaction:

$$
\begin{gathered}
\mathrm{Eu}\left(\mathrm{C}_{2} \mathrm{H}_{3} \mathrm{O}_{2}\right)_{3}+3 \mathrm{NH}_{3}+3 \mathrm{H}_{2} \mathrm{O} \\
\underset{\mathrm{NH}_{4} \mathrm{CH}_{3} \mathrm{COO}}{\stackrel{\text { B.P. } 114^{\circ} \mathrm{C}}{\Delta}} \underset{\mathrm{NH}}{\longrightarrow} \mathrm{NH}_{3}+\mathrm{CH}_{3} \mathrm{COOH} \uparrow
\end{gathered}
$$


Obviously, the decomposition of ammonium acetate is much easier than that of ammonium nitrate and ammonium chloride.

The EuAc ${ }_{3}-\mathrm{H}_{2} \mathrm{O}-\mathrm{isopropanol}$ system has been investigated. Even if the isopropanol contains only $0.2 \%$ or $0.4 \%$ water, channels are formed as each drop is dried and cracking gradually occurs.

The influence of different compositions of organic solvents on the quality of the targets has been investigated carefully. The results are listed in table 1.

Experiments showed that the mixture of ethanol and isopropanol is better than pure isopropanol for the uniform dispersion of the target material. A good quality target was obtained by using the optimum composition: from $4 \%$ ethanol ano $6 \%$ isopropanol to $6 \%$ ethanol and $4 \%$ isopropanol. More than $8 \%$ ethanol in isopropanol will produce small channels. In addition, the surface tension of the solution increases and evaporation is slower.

The solubility of acetate in isopropanol is rather small, but ethanol (proof 190, water concentration $5 \%$ ) increases the solubility of the acetate. Furthermore, it is beneficial in dispersing the target material.

In order to obtain good quality targets, the temperature of the substrate should be strictly controlled at 125 to $130^{\circ} \mathrm{C}$. If the temperature is too high, it is unfavorable for converting the acetate to the hydroxide because the organic solvent is vaporized too fast. If the temperature is 10 wer than $120^{\circ} \mathrm{C}$, the vaporization of the water is slower, and tiny channels will form on the surface of the layers.

Using the optimum composition of organic solutions, a number of $\tilde{\mathrm{Eu}}, \mathrm{O}_{3}$ and other $r$ are earth oxide targets were prepared, most of them with thicknesses of more than $1 \mathrm{mg} / \mathrm{cm}^{2}$. The crystals of the hydroxide or oxide forms are rather fine. If a drop of water is put on the surface of the target that is just finished, the deposits do not dissolve. This shows that the hydroxide has been formed and the ammonium acetate has heen decomposed. 
By careful heating at $450-550^{\circ} \mathrm{C}$, oxides were formed which were extremely resistant against scrubbing and were not washed away by water, alcohol or acetone.

Table 1. The effects on target quality of ethanol concentration in the acetate-isopropanol system Backing material: Al foil Diameter of target: $8 \mathrm{~mm}$

Evaporating temperature: $125-130^{\circ} \mathrm{C}$ Calcining temperature: $\quad 450-550^{\circ} \mathrm{C}$

\begin{tabular}{|c|c|c|c|}
\hline $\begin{array}{l}\text { Sample } \\
\text { No. }\end{array}$ & $\begin{array}{c}\text { Concentration of } \\
\text { Ethanol in Isopropanol } \\
\text { (vol. \%) }\end{array}$ & $\begin{array}{l}\text { Target } \\
\text { Thickness } \\
\left(\mathrm{mg} / \mathrm{cm}^{2}\right)\end{array}$ & Visual Observations \\
\hline 1 & $\begin{array}{l}100 \% \text { isopropanol* } \\
\text { (no ethanol) }\end{array}$ & $\begin{array}{l}1.00 \\
1.59 \\
3.37\end{array}$ & $\begin{array}{l}\text { Next drop cannot dissolve the } \\
\text { previously deposited material. } \\
\text { Dispersion is not good. }\end{array}$ \\
\hline 2 & $\begin{array}{l}2 \% \text { ethano } 1 \star \star \\
\left(\text { contains } 0.1 \% \mathrm{H}_{2} \mathrm{O}\right)\end{array}$ & 1.00 & Dispersion is not too uniform. \\
\hline 3 & $\begin{array}{l}4 \% \text { ethanol } \\
\text { (contains } 0.2 \% \mathrm{H}_{2} \mathrm{O} \text { ) }\end{array}$ & $\begin{array}{l}1.00 \\
1.20\end{array}$ & $\begin{array}{l}\text { Quality of each layer is } \\
\text { excellent, very uniform and } \\
\text { adherent, no cracking after } \\
\text { calcining. Crystals of } \\
\text { hydroxide are very fine. }\end{array}$ \\
\hline 4 & $\begin{array}{l}5 \% \text { ethanol } \\
\left.\text { (contains } 0.25 \% \mathrm{H}_{2} \mathrm{O}\right)\end{array}$ & $\begin{array}{l}1.00 \\
1.20 \\
5.00\end{array}$ & $\begin{array}{l}\text { Very uniform and adherent. No } \\
\text { crack ing after calcining. } \\
\text { Hydroxide crystals are very fine. }\end{array}$ \\
\hline 5 & $\begin{array}{l}6 \% \text { ethanol } \\
\left.\text { (contains } 0.3 \% \mathrm{H}_{2} \mathrm{O}\right)\end{array}$ & $\begin{array}{l}1.00 \\
2.50\end{array}$ & $\begin{array}{l}\text { Very uniform and adherent. No } \\
\text { cracking after calcining. } \\
\text { Hhydroxide crystals are fine. }\end{array}$ \\
\hline 6 & $\begin{array}{l}8 \% \text { ethano } 1 \\
\left(\text { contains } 0.4 \% \mathrm{H}_{2} \mathrm{O}\right)\end{array}$ & 1.00 & $\begin{array}{l}\text { There are several small grooves at } \\
\text { the center of target. }\end{array}$ \\
\hline 7 & $\begin{array}{l}10 \% \text { ethanol } \\
\left(\text { contains } 0.5 \% \mathrm{H}_{2} \mathrm{O}\right)\end{array}$ & 1.00 & $\begin{array}{l}\text { Grooves appeared as each drop } \\
\text { dried. Evaporation of drop } \\
\text { becomes slower. Surface } \\
\text { tension is higher. }\end{array}$ \\
\hline 8 & $\begin{array}{l}20 \% \text { ethanol } \\
\text { (contains } 1 \% \mathrm{H}_{2} \mathrm{O} \text { ) }\end{array}$ & 1.00 & $\begin{array}{l}\text { Many channels produced. } \\
\text { Deposit flaky after } \\
\text { calcining. Surface tension } \\
\text { even higher. }\end{array}$ \\
\hline
\end{tabular}


IV. Conclusion

Experiments show that the aqueous systems and water-organic solution systems do not work well. Comparison of the rare earth nitrate, chloride and acetate-organic solution systems demonstrate that the acetate system is the most satisfactory for the preparation of targets. This method solves the main problem - that each drop should not dissolve those previously deposited. The following procedures and conditions are recommended:

1. The rare earth compound is dissolved in glaciai acetic acid at $80-90^{\circ} \mathrm{C}$ to convert it to the acetate form.

2. The feed solution is pipetted into a centrifuge tube and oried. Water and. ethanol are then added to the tube and dried again to remove the acid.

3. The dried material is dissolved in a mixture of ethanol (95\% concn.) and isopropanol (the optimum composition is $4-6 \%$ ethanol in isopropanol).

4. Prior to the preparation of the target, the backing material is washeo and rinsed with suitable solvent by means of an ultrasonic cleaner.

5. Lacquer is sprayed onto the backing material around a mask which defines the area of deposit.

6. $20 \mu \mathrm{l}$ or $25 \mu \mathrm{l}$ stock solution is then pipetted on to the substrate by hand at $125-130^{\circ} \mathrm{C}$ at the same time $\mathrm{NH}_{3}$ gas is gently b?own over the surface.

7. Repeating the process, the deposits are increased until the desired thickness is obtained.

8. The target is placed in an oven and calcined at $450-550^{\circ} \mathrm{C}$ to convert the hydroxide to oxide and burn off the masking lacquer.

9. Thicker layers of target $\left(2500 \mu \mathrm{g} / \mathrm{cm}^{2}\right)$ can be produced by repeating the deposition in $200 \mu \mathrm{g} / \mathrm{cm}^{2}$ layers and calcining at $450-550^{\circ} \mathrm{C}$ after each layer is deposited. 
This method is suitable for making targets at least as thick as severai $\mathrm{mg} / \mathrm{cm}^{2}$. It is simple, fast, and convenient. There is no loss of material during the evaporation of the solution. The uniformity and adhesiveness of the targets is comparable to that of molecular plating.

We have designed this technique for the preparation of uniform and adherent targets, but it should also be admirably suited to the preparation of certain radioactive sources (such as $\alpha, \beta$ or $\gamma$ sources).

This method is also well suited to the preparation of targets or sources in which tiny droplets are sprayed onto the substrate in the presence of $\mathrm{NH}_{3}$ gas. Some preliminary work has been started which demonstrates that such a technique will be very valuable.

Besides the lanthanides, it should be possible to use this method for other elements, such as the actinides and those elements that form alcohol soluble acetates and form insoluble hydroxides with $\mathrm{NH}_{3}$ gas.

Acknowledgement: This work was supported by the Director, Office of Energy Research, Division of Nuclear Physics of the Office of High Energy and Nuclear Physics of the U.S. Department of Energy under Contract No. DE-AC03-76SF00098.

We are grateful to Professor Glenn T. Seaborg for his support, concern, and help. We wish to thank Or. M. Nurmia and H. L. Hall for their good suggestions. We also thank Diana Lee, Dr. K. E. Gregorich, R. M. Chasteler and Dr. H. A. O'Brian for their beneficial discussions. 


\section{References:}

1. K. Glover, P. Robinson; In Proceedings of the Seminar on the Preparation and Standardization of Isotope Targets and Foils, AERE-R 5097 (1965).

2. L. Yaffe, Ann. Rev. Nucl. Sci. 12, 153 (1962).

3. R. Lougheed, E. Hulet; Nucl. Inst. Meth. 166, 329 (1979).

4. S. H. Maxmann; Nucl. Inst. Meth. 50, 53 (1967).

5. D. Corswel1, J. Milstead; J. Nucl. Eng. 4, 5 (1967).

6. K.F. Lauer, V. Verdingh; Nuc1. Inst. Meth. 21, 161 (1963).

7. V. Verdingh, K.F. Lauer; Nucl. Inst. Meth. 49,179 (1967).

8. W. Cole, G. W. Grime; Preparation of Nuclear Targets for Particle Accelerators, p. 109 (1979).

9. J. Van. Audenhove, J. Pauwels; ibid, p. 79 (1979).

10. W. Porter, H. Bildstein, N. Getaff; Nucl. Inst. Meth. 26, 55 (1964).

11. W. Porter, H. Bildstein, N. Getaff; Nucl. Inst. Meth. 26, 61 (1964).

12. N. Getaff, H. Bildstein; Nucl. Inst. Meth. 36, 173 (1965).

13. N. Getaff, H. Bildstein; Nuc1. Inst. Meth. 70, 352 (1969).

14. J.E. Evans, R.W. Lougheed, M.S. Coops, R.W. Hoff and E.K. Hulet; Nucl. Inst. Meth. 102, $339(1972)$.

15. D.C. Aumann, G. Müllen; Nucl. Inst. Meth. 115, 75 (1974).

16. G. Müllen, D.C. Aumann; Nucl. Inst. Meth. 128, 425 (1975).

17. K.J. Moody, LBL-16249 (1983).

18. K.E. Gregorich, LBL-20192 (1985). 